HIJP : HEALTH INFORMATION JURNAL PENELITIAN

\title{
PENGARUH ELEVASI KEPALA 30 DERAJAT TERHADAP SATURASI OKSIGEN DAN KUALITAS TIDUR PASIEN STROKE
}

\author{
Sumirah Budi Pertami ${ }^{1}$, Siti Munawaroh ${ }^{2}$, Ni Wayan Dwi Rosmala ${ }^{3}$ \\ ${ }^{1}$ Jurusan Keperawatan, Poltekkes Kemenkes Malang, Indonesia: sumirahbudip@yahoo.com \\ ${ }^{2}$ Jurusan Keperawatan, Poltekkes Kemenkes Malang, Indonesia \\ ${ }^{3}$ Jurusan Keperawatan, Poltekkes Kemenkes Malang, Indonesia \\ (Korespondensi e-mail: sumirahbudi-@yahoo.com)
}

\begin{abstract}
ABSTRAK
Stroke adalah cedera serebral atau serangan otak yang terjadi karena kurangnya aliran darah dan oksigen ke otak yang terkait dengan obstruksi aliran darah ke otak atau pecahnya pembuluh darah serebral sehingga gangguan aliran oksigen ke otak menyebabkan hipokxia dan penderita mengalami gangguan kualitas tidur. Tujuan kajian ini adalah memastikan efek kepala atas posisi $30^{\circ}$ terhadap saturasi oksigen dan kualitas tidur pada pasien stroke di rumah sakit Dr. Soedarsono, Pasuruan. Desain studi ini quasi eksperimental dengan kelompok kontrol Nonequivalent. Populasi adalah pasien dengan stroke pada 14 Januari-9 Februari 2019 jumlah 34 pasien, sampel digunakan sampling berturut-turut. Hasil pada tes Mann-Whitney memperoleh nilai $\mathrm{P}=0,000(\mathrm{P}<0,05)$ dan $\mathrm{P}=0,001(\mathrm{P}<0,05)$ yang berarti bahwa ada efek memberi kepala posisi $30^{\circ}$ dalam kelompok pengobatan dan kelompok kontrol yang tidak diberikan intervensi untuk meningkatkan nilai saturasi oksigen dan kualitas tidur pada pasien stroke. Berdasarkan hasil penelitian ini diharapkan dapat menambahkan terapi posisi Head up $30^{\circ}$ dalam pelayanan keperawatan untuk meningkatkan saturasi oksigen dan kualitas tidur stroke pasien.
\end{abstract}

Kata kunci: Elevasi kepala $30^{\circ}$, Kualitas tidur, Saturasi oksigen, Stroke

Abstract

Stroke is a cerebral vesicular injury or brain attack that occurs due to lack of blood flow and oxygen to the brain associated with obstruction of blood flow to the brain or rupture of cerebral blood vessels so that disruption of oxygen flow to the brain causes hypoxia and sufferers to experience disorders sleep quality. The purpose of this study was ascertain the effect of head up $30^{\circ}$ position to oxygen saturation and sleep quality on stroke patient at Dr. Soedarsono Hospital, Pasuruan. Design on this study Quasi Experimental with Nonequivalent Control Group. Population was patients with stroke at 14 January -9 February 2019 amount 34 patients, sample used consecutive sampling. The results on the Mann-Whitney test obtained a value of $\mathrm{P}=0.000(\mathrm{P}<0.05)$ and $\mathrm{P}=0.001$ $(\mathrm{P}<0.05)$ which meant that there was an effect of giving head up $30^{\circ}$ position in the treatment group and the control group that were not given intervention to increase the value of oxygen saturation and sleep quality in stroke patients. Based on the results of this study is expected to apply head up $30^{\circ}$ position in nursing service to improve the oxygen saturation and sleep quality of patient stroke.

Keywords: Head up $30^{\circ}$ position, Oxygen saturation, Sleep quality, Stroke 


\section{PENDAHULUAN}

Stroke merupakan cidera vesikuler serebral (CVS) atau serangan otak yang berkaitan dengan obstruksi aliran darah pada otak (iskemik) atau pecahnya pembuluh darah otak (hemoragik). Stroke merupakan penyebab kematian ketiga setelah penyakit jantung dan kanker (Supadi, 2011).

Penyumbatan pembuluh darah atau pecahnya pembuluh darah merupakan penyebab terjadinya stroke, jika terjadi stroke maka aliran darah ke serebral menjadi tidak adekuat atau terganggu. hal ini dapat mengakibatkan ketidakseimbangan suplai oksigen di otak, dan metabolisme dalam otak akan mengalami gangguan. Jika masalah ini tidak segera ditangani maka otak yang tidak dialiri darah yang mengangkut oksigen maka dapat mengakibatkan hipoksia jaringan, dan metabolisme dalam otak juga terganggu yang dapat menimbulkan perubahan pada fungsi otak yang terkena. Individu yang beresiko mengalami stroke adalah diabetes, hiperkolesterolemia, lansia dengan hipertensi, atau penyakit jantung (Corwin, 2009).

Stroke dibagi menjadi 2 macam yaitu stroke iskemik (sumbatan pembuluh darah) dan stroke hemoragik (pecahnya pembuluh darah), di negara berkembang seperti Asia kejadian stroke hemoragik sebesar 30\% dan stroke iskemik $70 \%$. Setiap tahun 500.000 orang mengalami stroke, didapatkan $25 \%$ meninggal dunia, dan sisanya mengalami cacat berat dan ringan (Yastroki, 2013).

Menurut American Heart Assosiation (AHA, 2015) angka kejadian stroke pada laki-laki usia 20-39 tahun sebanyak 0,2\% dan perempuan sebanyak $0,7 \%$. Usia 40-59 tahun angka terjadinya stroke pada perempuan sebanyak $2,2 \%$ dan laki-laki $1,9 \%$. Prevalensi stroke pada usia lanjut semakin meningkat dan bertambah setiap tahunnya dapat dilihat dari usia seseorang 80 tahun keatas dengan angka kejadian stroke pada laki-laki sebanyak $15,8 \%$ dan pada perempuan sebanyak 14\%. Di Indonesia berdasarkan diagnosis pada penduduk umur $>15$ tahun menurut provinsi tahun 2013-2018 adalah $10.9 \%$ meningkat sebanyak 7\% dari tahun 2013 (Kementerian, Data Riset Kesehatan Dasar, 2018).

Prevalensi stroke di Jawa Timur berdasarkan diagnosis Nakes maupun diagnosis/gejala memiliki estimasi urutan ke 15 sebanyak 190.449 orang $(6,6 \%)$ dan 302.987 orang (10,5\%) (Riskesdas, 2013). Berdasarkan survey pendahuluan yang dilakukan diruang Interna 1 RSUD Dr.R.Soedarsono Pasuruan pada tanggal 22 Oktober 2018 didapatkan hasil data pasien stroke 3 bulan terakhir dari bulan Juli 2018 sampai bulan Oktober 2018 yaitu 111 kasus.

Stroke termasuk kasus kegawat daruratan dan membutuhksn pertolongan cepat dan tepat. Stroke adalah suatu serangan tiba tiba pada otak akibat gangguan pembuluh darah dalam mensuplai darah yang membawa oksigen dan glukosa untuk metabolisme sel sel otak agar tetap dapat melaksanakan fungsinya. Serangan ini bersifat mendadak dan dan menimbulkan gejala sesuai bagian otak yang tidak dialiri darah (Soeharto, 2004).

Penanganan stroke harus dilakukan dengan cepat dan tepat karena jika semakin lama stroke tidak segera ditangani maka tingkat keparahan stroke semakin tinggi, dan resiko kecacatan yang akan didapat makin memburuk karena meluasnya sel neuron yang mati dan daerah infark pada otak semakin meluas, bahkan dapat menyebabkan gangguan kesadaran dan kematian.

Salah satu komplikasi stroke yaitu gangguan sirkulasi serebral sehingga akan menyebabkan beberapa gejala diantaranya yaitu hipoksia jaringan serebral dan gangguan kualitas tidur. Berdasarkan studi empiris oleh Setyarini, et al (2017) membuktikan aliran darah yang tidak lancar pada pasien stroke mengakibatkan 
gangguan hemodinamik termasuk saturasi oksigen. Oleh karena itu perlu diperlukan pemantauan yang tepat karena kondisi hemodinamik sangat mempengaruhi penghantaran oksigen ke seluruh tubuh akhirnya akan mempengaruhi fungsi jantung (Hermawati, 2017).

Oksigen merupakan kebutuhan vital bagi setiap makhluk hidup, agar dapat mengukur berapa banyak prosentase oksigen yang terkandung dalam darah, atau di dalam air yang di minum ataupun oksigen di udara yang di hirup disebut sebagai saturasi oksigen (Hermawati, 2017).

Selain gangguan pada otak, seringkali ditemukan juga gangguan tidur berupa insomnia, hipersomnia, atau parasomnia. Keluhan berupa insomnia ditemukan 57\% $68 \%$ pasien stroke. Adanya gangguan tidur dipercayai dapat mempengaruhi perjalanan penyakit, melibatkan fungsi dan kualitas hidup, serta mordibitas dan mortalitas stroke. Stroke ditandai dengan adanya lesi otak yang akan menghasilkan defisit neurologis, pada sebuah penelitian diduga adanya pengaruh lesi pada bagian otak tertentu yang berpengaruh pada gangguan tidur. Gangguan tidur tersebut disebabkan oleh adanya depresi yang timbul ataupun adanya kerusakan otak (Maulidia, 2014).

Salah satu fungsi batang otak yaitu sebagai pengatur siklus bangun tidur dan pengatur tingkat kesadaran dan pengatur pusat pernafasan. Pada stroke terjadi penyumbatan dan aneurisme hal ini menyebabkan oksigen dan nutrisi tidak sampai ke neuron, dan menyebabkan gangguan metabolisme pada otak atau penurunan intake nutrisi pembentuk melantonin dan gangguan siklus tidurbangun seperti gangguan pernafasan saat tidur.

Pada sebuah penelitian didapatkan $25 \%$ pasien stroke yang masuk rumah sakit akan memperlihatkan pola nafas CheyneStrokes (CSR) saat tidur. CSR diduga disebabkan oleh disfungsi neurologis atau kurangnya peredaran darah ke otak yang dikaitkan dengan gagal jantung kongestif. Kerentanan untuk terjadi CSR selama tidur pada belahan otak yang terkena stroke mungkin menunjukkan adanya pengaruh jaringan infark atau sebuah respon inflamasi yang mempengaruhi regulasi bangun tidur (Kusumadjaja \& Cakrasana, $\mathrm{H}$ (2014)).

Menurut data empiris dari Bassetti (2011) melaporkan bahwa prevalensi gangguan tidur-bangun sebesar 20-40\% pada pasien yang terkena stroke. Kualitas tidur yang buruk dapat mempengaruhi derajat disabilitas pada pasien stroke. Untuk itu perlu observasi kualitas tidur pasien stroke untuk menghindari gejala keparahan stroke. Tindakan keperawatan yang dilakukan untuk dapat membantu tatalaksana pasien pasca serangan stroke yaitu terapi oksigen, pemberian nutrisi dengan cairan isotonik, pemberian nutrisi peroral, tirah baring total, membebaskan jalan nafas, dan mengatur posisi kepala lebih tinggi yaitu 30 derajat.

Intervensi yang dilakukan dalam penelitian ini yaitu terapi nonfarmakologi berupa tindakan elevasi kepala, posisi kepala yang paling umum yaitu menaikkan kepala dari tempat tidur sekitar 300, intervensi ini dilakukan pada pasien pasca serangan stroke. Elevasi kepala tujuannya untuk memepengaruhi venous return menjadi maksimal sehingga aliran darah ke serebral menjadi lancar, meningkatkan metabolisme jaringan serebral dan memaksimalkan oksigenasi jaringan otak, sehingga otak dapat bekerja sesuai fungsinya (Summers, dkk., 2009).

Menurut hasil penelitian terdahulu (Setyarini et al, 2017) ditarik kesimpulan bahwa dari penelitian ini adalah terdapat pengaruh posisi elevasi kepala $30^{\circ}$ terhadap saturasi oksigen pada pasien stroke hemoragik maupun non hemoragik karena dapat memfasilitasi peningkatan aliran darah ke serebral dan memaksimalkan oksigenasi ke jaringan serebral. Menurut penelitian oleh (Yaggi et al., 2011) mendapatkan bahwa resiko terkena stroke 
oleh sebab apapun lebih besar terjadi pada pasien dengan gangguan tidur terutama sleep apnea.

\section{METODE}

\section{Jenis Penelitian}

Desain penelitian ini menggunakan rancangan jenis eksperimen semu atau Quasi Eksperimental dengan menggunakan pendekatan Nonequivalent Control Group Design. Jenis penelitian Quasi Eksperimental adalah metode penelitian eksperimen dengan membandingkan hasil intervensi menggunakan kelompok kontrol, tetapi tidak sepenuhnya mengontrol variabel variabel luar yang mempengaruhi penelitian (Notoatmodjo, 2010).

Adapun Rancangan penelitian yang digunakan dalam penelitian ini sebagai berikut:

\section{Tabel 1. Desain Quasi Experimental}

Keterangan:

01: Pengukuran saturasi oksigen awal pada kelompok perlakuan sebelum diberikan intervensi

02: Pengukuran kualitas tidur awal pada

\begin{tabular}{|c|lll|}
\hline & Pre & Perlakuan & Post \\
Perlakuan & $0_{1} \mathrm{O}_{2}$ & $\longrightarrow \mathrm{X} \longrightarrow 0_{3} 0_{4}$ \\
Kontrol & $0_{5} \mathrm{O}_{6}$ & & $0_{7} 0_{8}$ \\
\hline
\end{tabular}

kelompok perlakuan sebelum diberikan intervensi

X: Pemberian intervensi elevasi kepala 300 pada kelompok perlakuan

03: Pengukuran saturasi oksigen akhir pada kelompok perlakuan sesudah diberikan intervensi

04: Pengukuran kualitas tidur akhir pada kelompok perlakuan sesudah diberikan intervensi

05: Pengukuran saturasi oksigen awal pada kelompok kontrol

06: Pengukuran kualitas tidur awal pada kelompok kontrol

07: Pengukuran saturasi oksigen akhir pada kelompok kontrol

08: Pengukuran kualitas tidur akhir pada kelompok kontrol

\section{Lokasi dan Waktu Penelitian}

Penelitian ini berlokasi di RSUD Dr. Soedarsono Pasuruan. Penelitian di laksanakan pada bulan periode Januari-Juni 2019.

\section{Populasi dan Sampel}

Populasi penelitian ini adalah Pasien stroke. yang rawat inap di Ruang Interna 1 di RSUD Dr. R. Soedarsono Pasuruan, Pemilihan yang dilakukan terhadap sampel, berdasarkan kriteria pasien yang bersedia ikut serta dalam penelitian menjadi responden dengan GCS 12-15.

\section{Pengumpulan Data}

Pengumpulan data dilakukan dengan menggunakan lembar observasi, Kuesioner Sleep Quality Index Pittsburgh (PSQI), Oksimetri, SOP Saturasi O2, SOP elevasi $30^{\circ}$. Dalam penelitain ini subyek penelitian dibagi menjadi 2 kelompok, yaitu kelompok perlakuan yang mendapatkan intervensi pemberian elevasi kepala $30^{\circ}$. Adapun kelompok kontrol yang tidak mendapatkan intervensi. Dalam penelitian ini peneliti mengobservasi saturasi oksigen dan kualitas tidur pada passien stroke sebelum dilakukan elevasi kepala $30^{\circ}$, kemudian diobservasi saturasi oksigen dan kualitas tidurnya setelah dilakukan elevasi kepala $30^{\circ}$.

Dimana saat sebelum dilakukan intervensi (pretest) terlebih dahulu dilakukan pengukuran saturasi oksigen dan kualitas tidur terhadap subjek. Setelah dilakukan intervensi (selama 3 hari, selanjutnya dilakukan pengukuran kembali saturasi oksigen dan kualitas tidur terhadap subjek posttest).

\section{Pengolahan dan Analisis Data}

Analisis univariat dalam penelitian ini adalah menjelaskan karakteristik dari responden meliputi: Usia (dalam bentuk Mean), jenis kelamin, pekerjaan, riwayat penyakit, yang ditampilkan dalam bentuk nilai distribusi frekwensi. 
Dalam penelitian ini untuk analisis bivariate menggunakan uji Wilcoxon sign rank test dan uji Mann Whitney karena sekala datanya menggunakan nonparametrik. Analisa bivariate uji Wilcoxon sign rank test digunakan untuk menguji dua sampel data yang saling berhubungan atau berpasangan (preposttest)

Saturasi oksigen dan kualitas tidur pada kelompok perlakuan dan kontrol yang memiliki data distribusi tidak normal, sedangkan analisa bivariate uji Mann Whitney digunakan untuk menguji dua sampel data yang tidak saling berhubungan (two independent samples) saturasi oksigen dan kualitas tidur pada kelompok kontrol dan pelakuan yang memiliki data distribusi tidak normal. Tingkat kemaknaan hasil uji statistik adalah 95\% dengan tingkat kesalahan ditetapkan sebesar 5\% $(\mathrm{a}=0,05)$. Jika hasil uji statistik didapatkan $\mathrm{p}<0,05$ maka $\mathrm{H} 0$ ditolak dan $\mathrm{H} 1$ diterima artinya ada pengaruh terapi elevasi kepala terhadap saturasi oksigen dan kualitas tidur pasien stroke

\section{HASIL}

Tabel 2. Saturasi Oksigen Sebelum dan Setelah Perlakuan

\begin{tabular}{|c|c|c|c|c|c|}
\hline \multicolumn{6}{|c|}{ Kelompok perlakuan } \\
\hline \multirow{3}{*}{$\begin{array}{l}\text { Sebelum } \\
\text { Sesudah }\end{array}$} & $\mathrm{N}$ & Mean & Min & \multirow{2}{*}{$\begin{array}{l}\text { Max } \\
95\end{array}$} & \multirow{2}{*}{$\begin{array}{l}\text { SD } \\
1,147\end{array}$} \\
\hline & \multirow[t]{2}{*}{17} & \multirow{2}{*}{$\begin{array}{l}93,76 \\
96,24 \\
\end{array}$} & \multirow{2}{*}{$\begin{array}{l}91 \\
94 \\
\end{array}$} & & \\
\hline & & & & 98 & 1,300 \\
\hline \multicolumn{6}{|c|}{ Kelompok kontrol } \\
\hline \multirow{3}{*}{$\begin{array}{l}\text { sebelum } \\
\text { sesudah }\end{array}$} & $\mathrm{N}$ & Mean & Min & $\operatorname{Max}$ & SD \\
\hline & 17 & 93,94 & 90 & 96 & 1,784 \\
\hline & & 92,53 & 84 & 96 & 3,538 \\
\hline
\end{tabular}

Table di atas menunjukkan bahwa rerata saturasi oksigen pada responden sebelum pada kelompok perlakuan adalah 93,76 dan sesudah pemberian elevasi kepala 30 derajat adalah 96,24 hal ini memiliki makna bahwa terdapat peningkatan nilai saturasi oksigen dengan selisih 2,48. Sedangkan nilai saturasi sebelum pada kelompok kontrol adalah 93,94 dan rerata saturasi oksigen sesudah adalah 92,53 hal ini memiliki makna bahwa saturasi oksigen setelah diberikan intervensi terjadi penurunan sebanyak 1,41

Tabel 3. Kualitas Tidur Sebelum dan Setelah Perlakuan

\begin{tabular}{|c|c|c|c|c|c|}
\hline \multicolumn{6}{|c|}{ Kelompok perlakuan } \\
\hline \multirow{3}{*}{$\begin{array}{l}\text { Sebelum } \\
\text { Sesudah }\end{array}$} & $\mathrm{N}$ & Mean & Min & Max & SD \\
\hline & 17 & 10,47 & 7 & 15 & 1,972 \\
\hline & & 6,65 & 3 & 10 & 1,618 \\
\hline \multicolumn{6}{|c|}{ Kelompok control } \\
\hline \multirow{3}{*}{$\begin{array}{l}\text { Sebelum } \\
\text { Sesudah }\end{array}$} & $\mathrm{N}$ & Mean & Min & Max & SD \\
\hline & 17 & 9,29 & 7 & 15 & 2,024 \\
\hline & & 8,88 & 5 & 13 & 1,900 \\
\hline
\end{tabular}

Nilai kelompok perlakuan adalah 10,47 dan rerata sesudah pada kelompok perlakuan adalah 6,65 hal ini memiliki makna bahwa kualitas tidur setelah diberikan intervensi tetap buruk tetapi terdapat penurunan nilai kualitas tidur dengan selesih 3,82. Sedangkan nilai kualitas tidur pada kelompok kontrol sebelum diberikan intervensi adalah 9,29 dan rerata sesudah pada kelompok kontrol adalah 8,88 termasuk kategori buruk, hal ini memiliki makna bahwa terdapat peningkatan nilai kualitas tidur sebanyak 0,41 .

Tabel 4. Analisis Pengaruh Elevasi Kepala 30 Derajat pada Pasien Stroke

\begin{tabular}{llccc}
\hline \multicolumn{5}{c}{ Saturasi Oksigen } \\
\hline & $\mathrm{N}$ & Mean & $\mathrm{SD}$ & $\mathrm{P}_{\text {value }}$ \\
\hline Sebelum & 17 & 96,76 & 1,300 & 0,000 \\
Sesudah & \multicolumn{5}{c}{ Kualitas Tidur } \\
\hline \multicolumn{5}{c}{3,538} \\
\hline Sebelum & 17 & Mean & $\mathrm{SD}$ & $\mathrm{P}_{\text {value }}$ \\
& 6,65 & 1,618 & 0,001 \\
Sesudah & & 8,88 & 1,900 \\
\hline
\end{tabular}

Hasil uji statistik menggunakan analisis bivariate Mann-Whitney U untuk menguji data tidak berpasangan saturasi oksigen dan kualitas tidur pasien pada kelompok perlakuan dan kelompok kontrol karena datanya berdistribusi tidak normal, 
pada tabel 4.5 didapatkan hasil untuk saturasi oksigen Pvalue $=0,00<\alpha=0,05$. Dan untuk kualitas tidur Pvalue $=0,001<\alpha$ $=0,05$.

Hasil uji Mann Whitney dapat diartikan bahwa ada pengaruh terapi elevasi kepala 30 derajat terhadap saturasi oksigen dan kualitas tidur pada pasien stroke.

\section{PEMBAHASAN}

\section{Nilai Saturasi Oksigen Sebelum dan Sesudah Pemberian Elevasi Kepala 30 pada Kelompok Perlakuan dan Kelompok Kontrol Pasien Stroke}

Hasil pengukuran saturasi oksigen menunjukkan bahwa rerata saturasi oksigen pada responden sebelum pada kelompok perlakuan adalah 93,76 hal ini memiliki makna bahwa saturasi oksigen termasuk kategori hipoksia ringan. Kemudian setelah diberikan intervensi elevasi kepala 300 selama 3 hari perlakuan didapatkan nilai rerata saturasi oksigen 96,76 termasuk kategori normal hal ini memiliki makna bahwa saturasi oksigen setelah diberikan intervensi terjadi peningkatan. Sedangkan nilai saturasi sebelum pada kelompok kontrol adalah 93,94 hal ini memiliki makna bahwa saturasi oksigen termasuk kategori hipoksia ringan, sedangkan rerata saturasi oksigen sesudah pada kelompok kontrol adalah 92,53 termasuk kategori hipoksia ringan, hal ini memiliki makna bahwa saturasi oksigen tidak diberikan intervensi terjadi penurunan. Pada penelitian ini penderita stroke berdasarkan dari kelompok umur sebagian responden berusia dibawah 50 tahun sebanyak 5 orang dan 29 orang diatas 50 tahun.

Stroke merupakan suatu gangguan fungsi otak lokal maupun luas yang terjadi secara mendadak, berlangsung lebih dari 24 jam, dapat menyebabkan kematian tanpa adanya penyebab lain selain vaskuler (Supadi, 2011). Stroke disebabkan gangguan pada suplai darah otak, biasanya karena pecahnya pembuluh darah atau terjadi sumbatan. Biasanya pada pasien stroke terjadi oklusi lumen (penyempitan pembuluh darah) yang disebabkan beberapa faktor antara lain aterosklerosis karena terdapat penyempitan pembuluh darah maka aliran darah ke jaringan akan menurun. Hal tersebut dapat menyebabkan ketidakseimbangan cairan diotak dan suplai oksigen ke otak menurun sehingga menyebabkan otak kekurangan oksigen dan mengalami hipoksia, jika komplikasi ini tidak segera ditangani maka akan mengalami iskemik otak bahkan kematian. Untuk itu perlu mengobservasi prosentase oksigen (saturasi oksigen) pasien pasca serangan stroke untuk mencegah terjadinya keparahan stroke.

Pemberian elevasi kepala $30^{\circ}$ dapat meningkatkan saturasi oksigen pada pasien stroke yang mana pengaturan posisi kepala yang lebih tinggi dari jantung dapat melancarkan aliran oksigen yang menuju ke otak serta dapat memfasilitasi peningkatan aliran darah serebral. Hal ini juga dibuktikan dengan teori menurut Summer,dkk. (2009) menunjukkan bahwa posisi kepala yang lebih tinggi dapat memfasilitasi peningkatan aliran darah serebral dan memaksimalkan oksigenasi jaringan seberal sehingga akan memicu pada peningkatan nilai saturasi oksigen.

Penelitian yang dikutip Khandelwal,dkk (2016) menambahkan elevasi kepala 30 derajat adalah dengan memposisikan pasien dengan punggung lurus dan elevasi kepala 30 derajat dengan tujuan untuk keamanan pasien dalam kelancaran pemenuhan oksigenasi.

Menurut peneliti pengukuran saturasi oksigen dapat diukur dengan menggunakan alat oxymetri. Yang mana cara pemakaiannya alat tersebut dijepitkan disalah satu ujung jari. Berdasarkan dari hasil yang diperoleh tersebut sudah jelas terlihat bahwa saturasi oksigen pada setiap orang berbeda dan banyak faktor yang mempengaruhi, seperti faktor usia, jenis kelamin, dan pola aktivitas. Usia dalam penelitian ini mayoritas diatas 50 tahun yaitu 29 responden. Semakin bertambahnya usia maka peningkatan nilai saturasi 
semakin lambat dikarenakan menurunnya beberapa fungsi organ seperti jantung.

Usia sebagai salah satu sifat karakteristik tentang organ, bertambahnya umur berhubungan dengan proses penuaan, dimana semua organ tubuh mengalami kemunduran fungsi termasuk pembuluh darah. Pembuluh darah dalam proses penuaan akan mengalami kemunduran fungsi, seperti pembuluh darah menjadi tidak elastis terutama bagian endotel yang mengalami penebalan, sehingga mengakibatkan lumen pembuluh darah semakin sempit dan berdampak pada penurunan aliran darah ke seluruh jaringan. Hal ini berhubungan dengan pengantaran oksigen ke jaringan menjadi tidak adekut. Sehingga akan mempengaruhi saturasi oksigen pada responden. Namun teori tersebut dapat diatasi dengan intervensi elevasi kepala $30^{\circ}$ pada pasien stroke untuk mengatasi masalah gangguan saturasi oksigen. Pada penelitian ini hasil observasi pada pasien stroke yang mengalami hipoksia setelah diberikan intervensi $30^{\circ}$ terdapat peningkatan nilai saturasi oksigen, dibandingkan dengan pada kelompok yang tidak diberikan intervensi 300 yang mayoritas mengalami penurunan nilai saturasi oksigen.

Pada penelitian ini jenis kelamin lebih banyak pada perempuan dengan jumlah 18 orang untuk perempuan dan 16 orang pada laki laki namun dalam teori kebanyakan menyatakan paling beresiko yaitu laki laki karena riwayat merokok, dan tidak menutup kemungkinan perempuan memiliki resiko tinggi terjadinya stroke karena faktor aktivitas yang kurang.

\section{Nilai Saturasi Oksigen Sebelum Dan Sesudah Pemberian Elevasi Kepala $30^{\circ}$ Pada Kelompok Perlakuan Dan Kelompok Kontrol Pasien Stroke}

Hasil pengukuran bahwa rerata kualitas tidur pada responden sebelum pada kelompok perlakuan dengan nilai 10,47 hal ini memiliki makna bahwa kualitas tidur termasuk kategori buruk, setelah diberikan intervensi elevasi kepala selama 3 hari didapatkan rerata kualitas tidur dengan nilai 6,65 termasuk kategori buruk hal ini memiliki makna bahwa kualitas tidur setelah diberikan intervensi tetap buruk tetapi terdapat penurunan nilai kualitas tidur dengan nilai selesih rata rata 3,82 antara sebelum dan sesudah pemberian intervensi. Sedangkan kualitas tidur pada kelompok kontrol sebelum dengan nilai 9,29, sedangkan rerata kualitas tidur sesudah pada kelompok kontrol dengan nilai 8,88 termasuk kategori buruk, hal ini memiliki makna bahwa kualitas tidur setelah diberikan intervensi tetap buruk.

Dapat disimpulkan pada kualitas tidur meskipun tidak dilakukan elevasi kepala $30^{0}$ dapat mempengaruhi kualitas tidur responden, akan tetapi jika dilakukan elevasi kepala $30^{\circ}$ (kelompok perlakuan) akan lebih besar peningkatan nilainya daripada kelompok yang tidak diberikan elevasi kepala $30^{0}$ (kelompok kontrol).

Ketika pembuluh darah otak terhambat oleh emboli atau trombus maka oksigen dan nutrisi tidak dapat mencapai neuron. Neuron yang kekurangan oksigen dan glukosa akan melepas glutamat secara berlebihan dari synaptic bulbs. Akibat dari pelepasan glutamat yang berlebih ini maka akan menjadi racun didalam otak, sehingga otak yang tidak dialiri oleh oksigen dan glukosa ini menjadi nekrosis karena tidak terjadi metabolisme pada jaringan tersebut (Nugroho \& Ikrar, 2014).

Hipertensi merupakan salah satu faktor resiko stroke yang disebabkan karena pola hidup yang buruk. Tekanan darah tinggi yang dibiarkan akan menyebabkan pergeseran dan penebalan arteri dinding pembuluh darah arteri, kondisi ini disebut dengan ateroskerosis yang menyebabkan penyumbatan pembuluh darah, termasuk pembuluh darah di otak. Hal ini bisa menyebabkan kematian jaringan otak tertentu sehingga akan mempengaruhi fungsi dari otak tersebut. 
Siklus tidur-bangun diatur di batang otak, jika pada daerah tersebut mengalami iskemik maka fungsi siklus bangun-tidur akan terganggu. selain itu pada daerah iskemik tidak terjadi metabolisme karen aliran darah yang tidak sampai ke jaringan otak maka akan mengakibatkan edema otak karena gagalnya pompa $\mathrm{Na}$ dan $\mathrm{K}$. Hal ini mengakibatkan perfusi serebral menurun dan tekanan intrakranial meningkat sehingga menimbulkan nyeri kepala yang dapat mengganggu kualitas tidur pasien stroke, sehingga pemberian posisi elevasi kepala $30^{\circ}$ salah satu terapi yang dapat digunakan untuk meningkatkan suplai nutrisi ke otak agar metabolisme diotak tidak terganggu dan dapat menurunkan nyeri kepala karena peningkatan tekanan intrakranial pada pasien stroke.

Hasil penelitian ini sejalan dengan penelitian Supadi (2008) Hasil uji hubungan proporsi didapatkan $p$ value $0.032<\alpha 0.05$ artinya ada hubungan yang signifikan antara posisi tidur semi fowler dengan kualitas tidur. Hasil penelitian ini menunjukkan bahwa posisi semifowler yang tepat akan mempengaruhi kualitas tidur klien, posisis elevasi kepala 30 derajat yang tepat untuk mengatasi pasien dengan gangguan kualitas tidur. Menurut hidayat (2006), kualitas tidur seseorang dikatakan baik apabila tidak menunjukkan tanda tanda kekurangan tidur dan tidak mengalami masalah dalam tidurnya. Tanda tanda kekurangan tidur dapat dibagi menjadi tanda fisik dan tanda psikologis.

Menurut peneliti kualitas tidur sesorang pada penelitian ini dapat dipengaruhi oleh faktor riwayat penyakit antara lain yaitu hipertensi, dalam penelitian ini responden mayoritas memiliki penyakit hipertensi sebanyak 16 responden dengan prosentase $47 \%$.

Hipertensi dapat disebabkan karena penyempitan atau terjadi sumbatan pembuluh darah sehingga oksigen dan nutrisi tidak sampai ke jaringan dengan maksimal, termasuk pada jaringan otak. Apabila terjadi emboli atau trombus pada pembuluh darah otak maka akan menyebabkan kematian jaringan otak tertentu sehingga tidak terjadi metabolisme yang dapat mengakibatkan edema otak, hal ini dapat mengakibatkan perfusi serebral menurun dan tekanan intrakranial meningkat sehingga menimbulkan nyeri kepala yang dapat mengganggu kualitas tidur responden. Maka salah satu tindakan untuk menguranginya adalah dengan menentukan posisi tidur pasien.

Selain itu kualitas tidur pada penelitian ini dapat dipengaruhi oleh factor lingkungan, seperti pencahayaan yang terlalu terang, ruangan bangsal yang ramai dan tidak dibatasi pengunjung, yang menimbulkan suara berisik sehingga mengganggu tidur pasien. Dengan mengarus posisi tidur, diharapkan pasien dapat terpenuhi kenyamanannya dan keluhan seperti nyeri kepala dapat teratasi. Dengan tidakan elevasi kepala $30^{\circ}$ tersebut diharapkan pasien mendapatkan kenyamanan dan meningkatkan kualitas tidurnya.

\section{Analisis Pengaruh Elevasi Kepala $30^{\circ}$ Pada Kelompok Perlakuan Dan Kelompok Kontrol Pada Pasien Stroke}

Hasil pengukuran saturasi oksigen pada responden setelah dilakukan pemberian elevasi kepala 30 derajat pada kelompok perlakuan diperoleh rata rata saturasi oksigen 96,24 mengalami peningkatan sedangkan pada kelompok kontrol yang tidak diberikan intervensi elevasi kepala 30 derajat didapatkan rata rata 92,53 mengalami penurunan. Hasil uji statistik menggunakan analisis bivariate Mann Whitney U untuk menguji data tidak berpasangan. Saturasi oksigen pada kelompok perlakuan dan kelompok kontrol apabila datanya berdistribusi tidak normal, pada tabel 4.3.3 menunjukkan Pvalue $=0,00<\alpha=0,05$ artinya ada pengaruh yang bermakna pada intervensi elevasi kepala 30 derajat terhadap peningkatan nilai saturasi oksigen. 
Hasil penelitian menunjukkan bahwa pasien stroke diruang rawat inap RSUD Dr. R. Soedarsono Pasuruan pada kelompok perlakuan dan kelompok kontrol sebagian memiliki nilai saturasi oksigen dalam kategori hipoksia ringan. Jika dibandingkan hasil dari kelompok perlakuan dan kelompok kontrol ada perbedaan yang lebih signifikan terhadap peningkatan nilai saturasi oksigen pada kelompok yang diberikan intervensi karena masing masing Pvalue intervensi bernilai tidak sama. Perbedaan antara kedua kelompok ini terdapat dalam besarnya peningkatan nilai saturasi yang terjadi, pada kelompok perlakuan terjadi peningkatan lebih banyak dibandingkan dengan kelompok kontrol. Hal ini dikarenakan pada kelompok kontrol tidak diberikan intervensi yang dilakukan oleh peneliti tetapi hanya bergantung pada intervensi yang dilakukan oleh pihak rumah sakit saja.

Dilihat dari perubahan nilai saturasi oksigen maka teknik pemberian elevasi kepala 30 derajat ini efektif dalam menaikkan nilai saturasi oksigen dibandingkan dengan kelompok yang tidak mendapat intervensi yang hanya diberikan pengobatan secara farmakologi.

Saturasi oksigen merupakan salah satu indikator dari status oksigenasi saat pasien di posisikan elevasi kepala 30 derajat gravitasi menarik diafragma kebawah sehingga memungkinkan ekspansi paru yang lebih baik saat klien berada dalam posisi elevasi kepala 30 derajat. Sehingga proses pernapasan bekerja baik (Kozier, 2009). Kemudian rotasi rateral dilakukan untuk meningkatkan ventilasi paru dan perfusi kejaringan serebral dan untuk mengoptimalkan pertukaran gas. Pengaturan elevasi kepala bertujuan memaksimalkan oksigenasi jaringan otak.

Menurut peneliti perubahan nilai saturasi yang terjadi pada setiap responden berbeda hal ini dapat disebabkan oleh beberapa faktor antara faktor yang mempengaruhi perubahan nilai saturasi oksigen, meliputi faktor usia, jenis kelamin, dan pekerjaan atau aktivitas setiap harinya. Pada penelitian ini usia pasien stroke yang menjadi responden bervariasi dari dewasa sampai usia lanjut, disini usia dapat mempengaruhi perubahan nilai saturasi oksigen karena usia merupakan ciri karakteristik dari berfungsinya organ tubuh manusia. pada penelitian ini jenis kelamin lebih banyak pada perempuan dengan jumlah memiliki resiko tinggi terjadinya stroke karena faktor aktivitas yang kurang, dengan kurangnya aktifitas maka lemak dalam tubuh akan terakumulasi bahkan dalam pembuluh darah, hal ini dapat mengakibatkan penyempitan pembuluh darah dan dapat mengganggu pengantaran oksigen ke seluruh jaringan termasuk jaringan serebral.

Sedangkan hasil pengukuran kualitas tidur pada responden setelah dilakukan pemberian elevasi kepala 30 derajat pada kelompok perlakuan menunjukkan bahwa ada perbedaan nilai kualitas tidur antara sebelum dan setelah diberi intervensi elevasi kepala 30 derajat. diperoleh rata rata nilai kualitas tidur 6,65 mengalami penurunan, sedangkan pada kelompok kontrol yang tidak diberikan intervensi elevasi kepala 30 derajat didapatkan rata rata 8,88 .

Hasil uji statistik menggunakan analisis bivariate Mann Whitney U untuk menguji data tidak berpasangan kualitas tidur pada kelompok perlakuan dan kelompok kontrol apabila datanya berdistribusi tidak normal, pada tabel 4.5 menunjukkan Pvalue $=0,001<\alpha=0,05$ artinya ada pengaruh yang bermakna pada intervensi elevasi kepala 30 derajat terhadap penurunan nilai kualitas tidur. Hasil penelitian menunjukkan bahwa pasien stroke diruang rawat inap RSUD Dr. R. Soedarsono Pasuruan pada kelompok perlakuan dan kelompok kontrol memiliki kualitas tidur yang buruk. Dibandingkan hasil dari kelompok perlakuan dan kelompok kontrol ada perbedaan yang lebih signifikan terhadap peningkatan nilai kualitas tidur pada kelompok yang 
diberikan intervensi karena masing masing Pvalue intervensi bernilai lebih kecil dari $\alpha=0,05$.

Perbedaan antara kedua kelompok ini terdapat dalam besarnya penurunan nilai kualitas tidur yang terjadi, pada kelompok perlakuan terjadi penurunan lebih banyak dibandingkan dengan kelompok kontrol. Hal ini dikarenakan pada kelompok kontrol tidak diberikan intervensi yang dilakukan oleh peneliti tetapi hanya bergantung pada intervensi yang dilakukan oleh pihak rumah sakit saja yaitu dengan terapi farmakologi.

Hasil penelitian ini sejalan dengan penilitian menurut Nugroho,dkk (2014) menjelaskan Ketika pembuluh darah otak terhambat oleh emboli atau trombus maka oksigen dan nutrisi tidak dapat mencapai neuron, Hal ini bisa menyebabkan kematian jaringan otak tertentu. Salah satu faktor penyebabnya yaitu riwayat penyakit hipertensi. Hipertensi diakibatkan karena pembuluh darah yang kehilangan keelastisannya sehingga tekanan untuk memompa darah dalam pembuluh darah menjadi tinggi, hipertensi yang tidak terkontrol dapat mengakibatkan emboli atau trombus yang dapat mengakibatkan edema otak karena gagalnya pompa $\mathrm{Na}$ dan K. Dan mengakibatkan perfusi serebral menurun dan tekanan intrakranial meningkat sehingga menimbulkan nyeri kepala yang dapat mengganggu kualitas tidur pasien stroke. Kemudian penelitian Supadi (2008) hasil uji hubungan proporsi didapatkan $\mathrm{P}$ value $0.032<\alpha 0.05$ artinya ada hubungan yang signifikan antara posisi tidur semi fowler dengan kualitas tidur. Hasil penelitian ini menunjukkan bahwa posisi semifowler yang tepat akan mempengaruhi kualitas tidur klien, posisis elevasi kepala 30 derajat yang tepat untuk mengatasi pasien dengan gangguan kualitas tidur.

Pemberian elevasi kepala 30 derajat menggunakan gaya gravitasi untuk membantu pernafasan, sehingga oksigen yang masuk kedalam paru paru akan lebih optimal sehingga pasien dapat bernafas lebih lega dan akan mengurangi ketidak nyamanan yang dirasakan ketika ingin tidur. Hal ini didukung oleh penelitian Melanie (2012) menganalisa pengaruh pemberian posisi semi fowler 300 dan 450 dan mendapatkan hasil bahwa terdapat pengaruh antara sudut posisi terhadap kualitas tidur akan tetapi tidak ada perbedaan berarti antara skor kualitas tidur kedua kelompok $(\mathrm{p} \leq 0,05)$.

Hal ini dapat dipengaruhi oleh beberapa faktor selain gangguan pernafasan antara lain faktor lingkungan yang kurang kondusif untuk mendapatkan istirahat optimal. Lingkungan yang terlalu berisik menyebabkan kesulitan tidur karena akan mengganggu ketenangan. Pasien juga dapat kesulitan tidur karena tekanan stress yang dirasakan, yang berujung pada ketakutan oleh proses penyakit dan tekanan dari lingkungan sekitar (Melanie, 2012).

Menurut peneliti, kualitas tidur sesorang dipengaruhi oleh faktor penyakit yaitu hipertensi yang diakibatkan karena penyempitan pembuluh darah dan jika tidak terkontrol akan mengakibatkan emboli atau trombus yang dapat mengakibatkan gangguan aliran darah ke jaringan. Faktor penyakit merupakan pengaruh terbesar yang mempengaruhi kualitas tidur sesorang, dalam penelitian ini riwayat penyakit pasien terbanyak yaitu dengan hipertensi dengan 16 responden dengan prosentase $47 \%$. Gejala yang sering ditimbulkan karena hipertensi yaitu nyeri kepala. Dengan ketidaknyamanan ini pasien menjadi terganggu tidurnya dan sulit untuk memulai tidurnya bahkan dapat terbangun dimalam hari karena nyeri kepala dan nyeri bagian tubuh yang lainnya.

Pada penelitian ini 34 responden mengalami kualitas tidur yang buruk, salah satunya akibat dari faktor lingkungan, seperti pencahayaan yang terlalu terang, ruangan bangsal yang ramai pengunjung menimbulkan suara berisik yang mengganggu tidur pasien, dan tindakan keperawatan yang dilakukan dimalam hari. Lingkungan fisik tempat seseorang tidur berpengaruh penting pada kemampuan 
untuk tertidur. Sehingga mengatur posisi tidur menjadi komponen yang harus diperhatikan untuk membantu kebutuhan istirahat dan tidur pasien terpenuhi. Dengan tindakan elevasi kepala 30 derajat diharapkan pasien dapat mendapatkan kenyamanan dan meningkatkan kualitas tidur khususnya pada pasien stroke

\section{KESIMPULAN DAN SARAN}

Hasil dari penelitian ini dapat disimpulkan bahwa pemberian elevasi kepala $30^{\circ}$ pada pasien stroke berpengaruh terhadap saturasi oksigen dan kualitas tidur pada pasien tersebut. Dimana tindakan ini dapat mempertahankan kestabilan fungsi dari kerja organ agar tetap lancar khususnya sistem pernafasan dan sistem regulasi dini yang bisa bekerja secara optimal serta memberikan kenyamanan bagi pasien stroke.

\section{DAFTAR PUSTAKA}

Arafat, R. Hapsah. (2016). Pengaruh Pemberian Posisi Lateral 300 Terhadap Tingkat Kenyamanan Pasien Stroke Dirumah Sakit Dr. Wahidin Sudirohusodo Makassar. Fakultas kedokteran Universitas Hasanuddin Makassar (http://injec.aipniainec.org/index.php/I NJEC/article/view/103/83) diakses pada tanggal 2 November 2018.

Corwin, Elizabeth J. (2009). Buku Saku Patofisiologi. Ed.3. Jakarta: EGC.

Dahlan, M, S. (2014). Statistic Untuk Kedokteran Dan Kesehatan. Jakarta: ECG.

Dinas Kesehatan Kabupaten/Kota. (2015). Profil Kesehatan Kabupaten Pasuruan Tahun 2015. Pasuruan: (www.depkes.go.id.) Diakses pada tanggal 24 September 2018.

Dinas Kesehatan Profinsi Jawa Timur. (2016). Profil Kesehatan Provinsi Jawa Timur Tahun $2016 . \quad$ Surabaya: (http://www.depkes.go.id.15_jatim_201

6) Diakses pada tanggal 24 September 2018.

Ekacahyaningtyas, M, dkk. 2017. Posisi Head Up 300 Sebagai Upaya Untuk Meningkatkan Saturasi Oksigen Pada Pasien Stroke Hemoragik Dan Non
Hemoragik. Surakarta: (https://akperadihusada.ac.id/jurnal/index.php/AHNJ/ article/view/98) diakses pada tanggal 2 November 2018.

Faizin, A. 2010. Pengaruh Pengaturan Posisi Kepala Pada Pasien Stroke. Padang:(http://repository.ump.ac.id/508 0/3/Ahmad\%20Faizin_BAB\%20II.pdf) diakses pada 23 September 2018.

Hermawati. (2017). Analisis Praktik Klinik Keperawatan Pada Pasien Stroke Dengan Intervensi Inovasi Pemberian Posisi Elevasi Kepala Untuk Meningkatkan Nilai Saturasi Oksigen Di Ruang Unit Stroke Rsud Abdul Wahab Sjahranie Samarinda Tahun 2017. Stikes Muhammadiyah Samarinda: (https://dspace.umkt.ac.id) diakses pada 4 Oktober 2018.

Kementrian Kesehatan Republik Indonesia. (2013) Pusat Data Dan Informasi Kementrian Kesehatan Republik Indonesia. Jakarta: (http://www.depkes.go.id/download.php ?file=download/pusdatin/infodatin/infod atin-stroke.pdf) diakses pada 24 September 2018.

Kowalak, Welsh \& Mayer. (2011). Buku ajar patofisiologi. Jakarta: EGC

McPhee S.J \& Ganong W.F. 2011. Patofisiologi Penyakit Pengantar Menuju Kedokteran Klinis, Edisi 5. Jakarta: EGC.

Muttaqin, Arif. 2012. Buku Ajar Asuhan Keperawatan Klien dengan Gangguan Sistem Pernafasan. Jakarta: Salemba Medika.

Notoatmodjo, S. 2012. Metodologi Penelitian Kesehatan. Jakarta: Rineka Cipta.

Nursalam, 2008. Konsep Dan Penerapan Metodologi Penelitian Ilmu Keperawatan Pedoman Skripsi, Tesis, Dan Instrument Penelitian Keperawatan. Jakarta: Salemba Medika.

Nursalam, 2013. Konsep Penerapan Metode Penelitian Ilmu Keperawatan. Jakarta: Salemba Medika.

Pearce, Evelyn C. 2013. Anatomi Dan Fisiologi Untuk Paramedis, Edisi 4. Jakarta: PT Gramedia Pustaka Utama, Anggota IKAPI.

Pertami, S.B, et al. (2017). Effect Of $30^{\circ}$ HeadUp Position On Intracranial Pressure Change In Patients With Head Injury In Surgical Ward Of General Hospital Of Dr. R. Soedarsono Pasuruan. Department 
of Nursing, Polytechnic of Health of Malang Ministry of Health Republic of Indonesia.

(http://stikbar.org/ycabpublisher/index.p $\mathrm{hp} / \mathrm{PHI} /$ index) diakses pada 28 Oktober 2018.

Potter, P.A, \& Perry, A.G. 2006. Buku Ajar Fundamental Keperawatan: Konsep, Proses dan Praktik, Edisi 4 Volume 2. Jakarta: EGC.

Priyo, E. (2015). Pengaruh Terapi Rendam Kaki Air Hangat Terhadap Peningkatan Kualitas Tidur Lansia Di Desa Argopeni Kecamatan Ayah Kabupaten Kebumen. Purwokerto: (respiratory.ump.ac.id) diakses pada tanggal 4 November 2018.

Riskesdas, 2013. Profil Kesehatan Indonesia, Data Dan Informasi Tahun 2013. Jakarta: Badan Penelitian dan Pengembangan Kementrian Kesehatan RI.

Sekeon, S.A dkk. (2015). Hubungan Antara Kualitas Tidur Dengan Keparahan Stroke. Jurnal e-Clinic (eCl), Volume 3, Nomor 3. (https://ejournal.unsrat.ac.id/index.php/e clinic/article/view/10445) diakses pada tanggal 1 November 2018.

Setiadi. 2007. Konsep Dan Penulisan Riset Keperawatan Edisi Pertama. Graha Ilmu : Yogyakarta.

Setiadi. (2013). Konsep \& Penulisan Riset Keperawatan Edisi Kedua. Yogyakarta: Graha Ilmu.

Setyopranoto, I. (2011). Gejala dan Penatalaksanaan Stroke. Yogyakarta: (http://www.kalbemed.com/Portals/6/1 05 185Strokegejalapenatalaksanaan.pdf ) diakses pada 03 November 2018.

Stroke Indonesia. (2016). Stroke. Copyright (C) 2016 Hospital Authority. All rights reserved

(https://www.google.co.id/url?sa=t\&sou rce=web\&rct=j\&url=http://www21.ha.or g.hk/smartpatient/EM/MediaLibraries/E $\mathrm{M} /$ EMMedia/Stroke) diakses pada 2 Oktober 2018.

Sugiyono, 2012. Metode Penelitian Kuantitatif Kualitatif Dan R\&D. Bandung: Alfabeta. Supadi, 2011. Pengaruh Elevasi Posisi Kepala Pada Klien Stroke Hemoragik Terhadad
Tekanan Rata-Rata Arterial, Tekanan Darah Dan Tekanan Intra Kranial Di Rumah Sakit Margono Soekarjo Purwokerto Tahun 2011. Purwokerto: (jos.unsoed.ac.id) diakses pada tanggal 23 September 2018

Sunarto. (2015). Peningkatan Nilai Saturasi Oksigen Pada Pasien Stroke Menggunakan Model Elevasi Kepala.Jurnal Terpadu Ilmu Kesehatan, Volume 4, Nomor 1. Kementrian Kesehatan Politeknik Kesehatan Surakarta Jurusan Keperawatan. http://jurnal.poltekkes-

solo.ac.id/index.php/Int/article/view/115 . Diakses tanggal 14 November 2018.

Sujarweni, Wiratna. (2015). Statistic Untuk Kesehatan. Yogyakarta: Gava Media.

Sulistyowati, D. (2015). Pengaruh Sudut Posisi Tidur Terhadap Kualitas Tidur Terhadap

Kualitas Tidur Dan Status Kardiovaskuler Pada Pasien Infark Miokard Akut Diruang ICVCU RSUD Dr. Moewardi Surakarta. Jurnal Kesmadaska (http://id.portalgaruda.org/?ref=browse $\& \bmod =$ viewarticle $\&$ article $=153496$ ) diakses pada tanggal 1 November 2018.

Wilson, L. M. \& price, S. A. (2005). Patofisiologi Konsep Klinis Proses Proses Penyakit. Ed. 6. Jakarta: EGC.

\section{INFORMASI TAMBAHAN}

\section{Lisensi}

Hakcipta (c) 2019 Health Information : Jurnal Penelitian

artikel akses terbuka ini dapat disebarkan seluas-luasnya sesuai aturan Creative Commons Attribution-ShareAlike 4.0 International License dengan catatan tetap menyebutkan penulis dan penerbit sebagaimana mestinya.

Catatan Penerbit: Poltekkes Kemenkes Kendari menyatakan tetap netral sehubungan dengan klaim dari perspektif atau buah pikiran yang diterbitkan dan dari afiliasi institusional manapun. 